\title{
Neuronal Growth Factors from Tumours of Von Recklinghausen Neurofibromatosis
}

\author{
Richard J. Riopelle and Vincent M. Riccardi
}

\begin{abstract}
Explants of 21 neurofibromas from 16 patients with Von Recklinghausen neurofibromatosis (NF-I) plus tumour tissue from 5 comparison patients and normal tissue from one of the NF-I patients were assayed for neuronal growth factor(s) using dissociated embryonic sensory neurons from chick embryo. Twenty-one of 21 neurofibroma explants released detectable quantities of neuronal growth factors, but only 2 of 8 non-neurofibroma tissue explants released activity.

While antiserum to mouse nerve growth factor (NGF) fractionally inhibited neurite outgrowth induced by some of the neurofibromas, overall differences between assays containing antibody and controls reached statistical significance in 3 cases; in one case, explants of a separate tumour from the same patient had no detectable NGF-like activity.

These data support the hypothesis that local release of neuronal growth factors in neurofibromas are responsible for neurites observed within these tumours. Further evidence that endoneurial tissue of peripheral nerve is a rich source of heterogeneous neuronal growth facts has been provided by these studies.
\end{abstract}

RÉSUMÉ: Facteur de croissance neurotrope extrait de tumeurs provenant de patients souffrant de neurofibromatose de von Recklinghausen Au moyen de neurones sensitifs embryonnaires dissociés provenant d'embryons de poulet, nous avons dosé le facteur de croissance neurotrope dans des explants de 21 neurofibromes provenant de 16 patients atteints de neurofibromatose de von Recklinghausen (NF-I), ainsi que dans du tissu tumoral provenant de 5 patient\$ contrôles et dans du tissu normal provenant d'un des patients avec NF-I. Vingt-et-un des 21 explants neurofibromateux libéraient des quantités détectables de facteur de croissance neurotrope. Cependant, seulement 2 des 8 explants non-neurofibromateux libéraient cette substance active.

Bien que l'antisérum dirigé contre le facteur de croissance neurotrope (FCN) inhibait de façon fractionnaire les excroissances des neurites induites par certains des neurofibromes, dans l'ensemble, les différences entre les dosages dans les expériences avec anticorps et les expériences contrôles étaient statistiquement significatives dans 3 cas; dans un cas, des explants d'une autre tumeur provenant du même patient n'avaient pas d'activité analogue au FCN détectable.

Ces données sont en faveur de l'hypothèse selon laquelle la libération locale de facteurs de croissance neurotropes dans les neurofibromes est responsable des neurites observés à l'intérieur de ces tumeurs. Ces études ont fourni d'autres preuves que le tissue de l'endonèvre des nerfs périphériques est riche en facteurs de croissance neurotropes hétérogènes.

Can. J. Neurol. Sci. 1987; 14:141-144

Neurofibromatosis (NF) is a heterogeneous disease which includes Von Recklinghausen neurofibromatosis (NF-I). NF-I is distinguished from other forms of NF on the basis of large numbers of cafe-au-lait spots, cutaneous neurofibromas, and iris Lisch nodules; these findings are often associated with other features as reviewed by Riccardi. ${ }^{1}$

The influence of nerve growth factor on cells of neural crest origin and the presumed crest derivation of NF lesions have stimulated a number of studies ${ }^{2-7}$ of circulating NGF levels in $\mathrm{NF}$ in order to establish a reliable laboratory marker for neurofibromatosis. We have demonstrated recently that human serum contains neuronal growth factors but that the level of the factors does not contribute to identification of the NF-I phenotype. ${ }^{8}$

Despite compelling evidence that peripheral nerve endoneurium contains both NGF and non-NGF material, 9.10 .11 little attention has been devoted to a study of neuronal growth factors in the peripheral nerve tumours of NF patients. Using a sensitive neuronal cell biological assay, ${ }^{12}$ we report here detection of neuronal growth factors from explants of tumours of a rela-

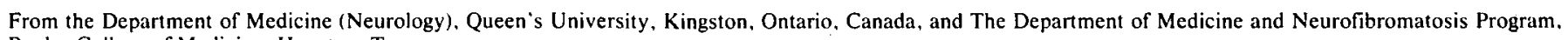
Baylor College of Medicine, Houston. Texas

Received September 24, 1986. Accepted January 6, 1987

Reprint requests to: Dr. R.J. Riopelle, La Salle Building, Queen's University, Kingston, Ontario Canada K7L 3N6 
tively homogeneous group of NF-I patients.

\section{METHODS}

Tissue Explants Tissue collected by one of us (VMR) between 1982 and 1984 was harvested at the time of surgery and frozen immediately at $-80^{\circ} \mathrm{C}$. Material was stored at this temperature until used in the assays. At the time of assay $1 \mathrm{~mm}^{3}$ explants were prepared aseptically with a scalpel using pieces of tissue that appeared on gross examination to be homogeneous. Mean ( \pm S.D.) protein per explant analyzed by the method of Lowry et al ${ }^{13}$ was $163 \pm 7 l \mu \mathrm{g}$. A single $1 \mathrm{~mm}^{3}$ piece of tissue was added to each cultural well. For each assay at least two explants of tissue were analyzed, and a minimum of four separate assays were carried out for each tissue.

\section{Bioassay}

The bioassay was based upon a chick embryo single sensory neuron culture system developed as a sensitive biological assay for NGF. ${ }^{12.14}$ In the assay, culture wells of Falcon microculture plates were coated with poly-D-lysine $(0.1 \mathrm{mg} / \mathrm{ml}, 24 \mathrm{~h}$, $37^{\circ} \mathrm{C}$ ). Following washes of the wells, a suspension of 10,0007 . to 8-day dorsal root ganglion cells enriched for neurons by preplating was added to each well in a total volume of $200 \mu \mathrm{l}$ of supplemented Ham's $\mathrm{F} 12$ medium ${ }^{12}$ with $5 \%$ fetal calf serum. A single $1 \mathrm{~mm}^{3}$ explant of tissue was added to each well. Control wells contained NGF ( $4 \mathrm{pM}$ ) or no NGF. In addition, each well contained $5 \mu \mathrm{l}$ heat-inactivated $\left(56^{\circ} \mathrm{C}, 30 \mathrm{~min}\right)$ rabbit anti-NGF antiserum (final concentration $1 / 200$ ), or $5 \mu$ l of a similar dilution of heat-inactivated pre-bleed normal rabbit serum (NRS). Antiserum concentration was 1000 -fold in excess of that required to completely inhibit neurite outgrowth produced by NGF (4 pM).

Culture plates were incubated for $24 \mathrm{~h}\left(37^{\circ} \mathrm{C}, 5 \% \mathrm{CO}_{2}\right)$ and then scored for percent neurite-bearing cells. At least one hundred phase bright cells in a representative field of each well were counted using a Leitz Diavert microscope with phase optics. This assay measures numbers of neurons with processes in excess of 1.5 cell diameters but does not quantitate process length, another parameter that can be used for neurotrophic activity. One of us (RJR) scored all assays without knowledge of the source of tissue. Results were matched to the tissue of origin by VMR.

\section{Materials}

NGF was prepared using the method of Mobley et al. ${ }^{15}$ Rabbit antimouse NGF was prepared as previously described. ${ }^{8}$ Commercial sources were used to purchase all chemicals and media: trypsin (TRPCK) from Worthington Biochemical Corporation; Ham's F12, Hank's balanced salt solution, fetal calf serum from GIBCO; poly-D-lysine from SIGMA; carboxymethyl cellulose (CM52) from Whatman; ampholytes from LKB; gel electrophoresis materials from BioRad; fertilized White Leghorn eggs were purchased from H\&M Poultry and Waterfowl and incubated in a home-made egg incubator.

\section{RESULTS}

The single neuronal cell assay reliably gave background neurite outgrowth of $5 \pm 5 \%$ in the absence of NGF and values of
$67 \pm 9 \%$ (Mean \pm SD) in the presence of 4 pM NGF. These data are consistent with findings of the dose response of sensory neurons to NGF where, between 3 and $4 \mathrm{pM}$, approximately $70 \%$ of neurons bear processes at 24 to $48 \mathrm{~h} .{ }^{14}$ In the assay of explants, data were expressed as percent neurite outgrowth per $1 \mathrm{~mm}^{3}$ explant both in the presence of antiserum to NGF and in the presence of prebleed normal rabbit serum at the same dilution. Control wells in the absence of rabbit serum were not different from wells containing normal rabbit serum (data not shown).

Table 1 indicates that 21 of 21 tumours from 16 patients contained detectable neuronal growth factor activity (Mean \pm $\mathrm{SD}, \mathrm{n}=8$ ). In four cases, percent neurite outgrowth was in excess of that observed with the maximal response to NGF. This observation, and the finding that neurite outgrowth was inhibited only partially by anti-NGF, is evidence of the heterogeneity of the explant-released activity. Table 1 also shows the neuronal response in the presence of anti-NGF. Overall, the inhibition by anti-NGF suggesting the presence of growth fac-

\begin{tabular}{|c|c|c|c|}
\hline \multirow[b]{2}{*}{ Patier } & \multirow[b]{2}{*}{ Specimen } & \multicolumn{2}{|c|}{ \% Neurite-bearing Cells } \\
\hline & & Control & Anti-NGF \\
\hline \multirow[t]{2}{*}{1} & $\mathrm{nf}$ & $90.2 \pm 12.2$ & $70.3 \pm 11.6^{* *}$ \\
\hline & $\mathrm{nf}$ & $81.5 \pm 11.9$ & $79.0 \pm 4.9$ \\
\hline 2 & $\mathrm{nf}$ & $62.3 \pm 28.6$ & $62.5 \pm 20.6$ \\
\hline 3 & $\mathrm{nf}$ & $14.1 \pm 11.3$ & $12.8 \pm 16.8$ \\
\hline 4 & $\mathrm{nf}$ & $76.9 \pm 15.4$ & $64.5 \pm 15.6$ \\
\hline 5 & $\mathrm{nf}$ & $48.5 \pm 21.3$ & $39.8 \pm 12.0$ \\
\hline 6 & $\mathrm{nf}$ & $54.7 \pm 10.9$ & $47.5 \pm 6.4$ \\
\hline 7 & $\mathrm{nf}$ & $33.3 \pm 4.0$ & $41.5 \pm 16.0$ \\
\hline 8 & $\mathrm{nf}$ & $39.3 \pm 15.4$ & $21.8 \pm 8.3$ \\
\hline \multirow[t]{2}{*}{9} & $\mathrm{nf}$ & $34.7 \pm 22.5$ & $45.3 \pm 8.7$ \\
\hline & $\mathrm{nf}$ & $33.1 \pm 19.5$ & $30.5 \pm 23.1$ \\
\hline \multirow[t]{2}{*}{10} & $\mathrm{nf}$ & $56.6 \pm 30.8$ & $34.3 \pm 15.2$ \\
\hline & $\mathrm{nf}$ & $29.5 \pm 22.8$ & $31.1 \pm 22.5$ \\
\hline 11 & $\mathrm{nf}$ & $64.3 \pm 14.9$ & $44.0 \pm 7.1^{*}$ \\
\hline 12 & $\mathrm{nf}$ & $51.7 \pm 17.5$ & $61.8 \pm 16,3$ \\
\hline \multirow[t]{3}{*}{13} & $\mathrm{nf}$ & $66.7 \pm 7.9$ & $67.3 \pm 16.0$ \\
\hline & $\mathrm{nf}$ & $27.5 \pm 22.9$ & $35.8 \pm 25.9$ \\
\hline & $\mathrm{nf}$ & $46.9 \pm 28.2$ & $46.8 \pm 23.9$ \\
\hline 14 & $\mathrm{nf}$ & $40.3 \pm 23.7$ & $43.9 \pm 20.6$ \\
\hline 15 & nf & $14.1 \pm 8.7$ & $13.0 \pm 12.1$ \\
\hline 16 & $\mathrm{nf}$ & $71.7 \pm 13.2$ & $51.8 \pm 18.4^{* * *}$ \\
\hline 13 & liv & $0 \S$ & 0 \\
\hline 17 & men & $36.3 \pm 4.8$ & $27.5 \pm 5.0$ \\
\hline \multirow[t]{3}{*}{18} & wt & 0 & 0 \\
\hline & wt & 0 & 0 \\
\hline & wt & 0 & 0 \\
\hline 19 & wt & $19.7 \pm 20.9$ & $24.9 \pm 27.0$ \\
\hline 20 & $\mathrm{nb}$ & 0 & 0 \\
\hline 21 & $\mathrm{nb}$ & 0 & 0 \\
\hline \multicolumn{2}{|c|}{$\mathrm{p}<.05$} & $\mathrm{nf}$ & neurofibroma \\
\hline \multicolumn{2}{|c|}{${ }^{*} \quad \mathrm{p}<.02$} & $w$ & Wilm's tumour \\
\hline \multicolumn{2}{|c|}{$* * \quad \mathrm{p}<.01$} & $\mathrm{n}$ & neuroblastoma \\
\hline$\S$ & $\begin{array}{l}\% \text { neurite-bearing } \\
\text { cells was } 5 \% \text { or less. }\end{array}$ & $\begin{array}{l}\text { men } \\
\text { liv }\end{array}$ & $\begin{array}{l}\text { meningioma } \\
\text { liver }\end{array}$ \\
\hline
\end{tabular}

Cultures of neurons were prepared as described in Materials and Methods. At 24 hours, culture wells were scored for the percentage of viable cells with processes exceeding 1.5 cell diameters. Results are expressed as means and standard deviations of assays set up in duplicate and carried out four times. 
tor immunologically cross-reactive with mouse NGF was not significant. However, with three neurofibroma explants, there was a statistically significant inhibition, suggesting the presence of a NGF-like molecule.

Comparisons for this study were comprised of seven tumours from five patients, and normal tissue from one patient with NF-I who provided three neurofibromas for assay. Of the comparison tumours, one of four Wilm's tumours had low but detectable activity, while no activity from either of two neuroblastomas could be detected. One meningioma had levels of activity comparable to some of the neurofibromas. The normal tissue, liver from a patient with neurofibromatosis, had no detectable activity.

\section{Discussion}

In recent studies of serum neuronal growth factors in Von Recklinghausen neurofibromatosis ${ }^{8}$ and in the present studies, the problem of clinical heterogeneity that has made interpretation of previously reported biological data difficult has been minimized by using material from well-characterized NF-I patients. As in the serum studies, we have employed a biological assay system which minimized the contribution of contaminating non-neuronal cells that are a source of neuronal growth factor activity. ${ }^{14,16}$ Furthermore, it has been possible, using the sensory neuronal cell assay, to detect growth factor heterogeneity and immunological homology of tissue-released NGFlike activity with NGF of murine origin. ${ }^{9.14}$

The present studies provide semi-quantitative data demonstrating that $100 \%$ of NF-I tumours tested released neuronal growth factors. In only three cases, however, did anti-NGF significantly inhibit the neurite-promoting activity released by the tumours, suggesting the presence of molecular species homologous to mouse NGF. The percent inhibition of neuronal performance by anti-NGF in three tumours averaged 27 percent. This figure is consistent with the percent inhibition by anti-NGF of neuronal growth factor activity from explants of peripheral nerve in vitro in two previous studies. ${ }^{9.10}$ It is of interest that in one instance another neurofibroma from the same patient released neurite-promoting material with no detectable NGF-like activity; this observation suggests that autologous neurofibromas could behave independently. One tumour in the comparison group of tumours - a meningioma - had levels of neuronal growth factor activity comparable to that released by some neurofibromas. The other tumours and normal tissue that were tested had little or no activity. It is possible that the higher levels in the meningioma relates to its presumptive embryonic origin from neural crest structures, ${ }^{17}$ but two undifferentiated neuroblastomas, also of the same embryonic origin, ${ }^{18}$ had no activity.

The wide variability of the assay scores in the presence of explants contrasts with the highly reproducible values seen with NGF. This observation might suggest different kinetics of release of neuronal growth factors from individual tissue explants. More precise quantitation with less variance might have been achieved by using extracts of tumour homogenates, but wide variability was also observed when serum extracts were assayed for similar activity in a recent study. ${ }^{8}$

The present observations that neurofibromas are a rich source of neuronal growth factor activity support the hypothesis advanced previously ${ }^{8,18}$ that local release of growth-promoting materials is responsible for neurites observed within neurofibromas. ${ }^{19}$ Previous studies ${ }^{8}$ demonstrating that serum levels of neuronal growth factors in NF-I patients do not distinguish this phenotype from comparison subjects suggests that the tumour activity is not released to the general circulation. The present data also add further support to previous observations that both NGF and non-NGF neuronal growth factors are produced by endoneurial cells of peripheral nerve. ${ }^{9,10,11}$

Important goals of future research will be the characterization of non-NGF neuronal growth factors in peripheral nerve. Neurofibromas are a readily available source of such material and may also be a rich depot of those molecular species that are involved in proliferation of endoneurial elements within the tumours.

\section{ACKNOWLEDGEMENTS}

This work was supported by the Physicians' Services Incorporated Foundation of Ontario (RJR) and the Texas Neurofibromatosis Foundation (VMR). The excellent technical assistance of $S$. Faulkner is acknowledged. The authors are grateful to Mrs. S. McCaughey who typed the manuscript.

\section{REFERENCES}

1. Riccardi VM. Von Recklinghausen neurofibromatosis. New Eng J Med 1981; 305: 1617-1627.

2. Fabricant RN, Todaro GJ. Increased serum levels of nerve growth factor in Von Recklinghausen's disease. Arch Neurol 1981:38: 401-405.

3. Siggers DC. Nerve growth factor and some inherited neurological conditions. Proc R Soc Med 1976; 69: 183-184.

4. Rubenstein AE, Mytilineoau C, Yahr MD, et al. Neurological Aspects of Neurofibromatosis. In: Riccardi VM, Mulvihill JJ, eds. Advances in Neurology 29. Neurofibromatosis. New York: Raven Press, 1981: 11-20.

5. Schenkein I, Bueker ED. Helson L, et al. Increased nerve growth stimulating activity in disseminated neurofibromatosis. New Eng J Med 1974; 290; 613-614.

6. Siggers DC, Boyer SH, Eldridge R. Nerve Growth Factor in disseminated neurofibromatosis. New Eng J Med 1975: 292:1134.

7. Tischler AS. Quantitation of nerve growth stimulating activity. New Eng J Med 1974; 290: 1203.

8. Riopelle RJ, Riccardi VM, Faulkner S, et al. Serum neuronal growth factor levels in Von Recklinghausen neurofibromatosis. Ann Neurol 1984; 16: 54-59.

9. Riopelle RJ, Boegman RJ, Cameron DA. Peripheral nerve contains heterogeneous growth factors that support sensory neurons in vitro. Neurosci Lett 1981; 25: 311-316.

10. Richardson PM, Ebendal T. Nerve growth activities in rat peripheral nerve. Brain Res 1982; 246: 57-64.

11. Longo FM, Manthorpe M, Skaper SD, et al. Neuronotrophic activities accumulate in vivo within silicone regeneration chambers. Brain Research 1983; 261: 109-117.

12. Sutter A, Riopelle RJ, Harris-Warrick RM, et al. The heterogeneity of Nerve Growth Factor Receptors. In: Bitensky M, Collier RJ, Fox CF, eds. Progress in Clinical and Biological Research 31. New York: Liss Inc, 1979: 659-667.

13. Lowry OH, Rosebrough NJ, Farr AL, et al. Protein measurement with the folin phenol reagent. J Biol Chem 1951; 193: 265-275.

14. Riopelle RJ, Cameron DA. Neurite growth promoting factors of embryonic chick - ontogeny, regional distribution and characteristics. J Neurobiol 1981; 12: 175-186. 
15. Mobley WC, Schenker A, Shooter EM. Characterization and isolation of proteolytically modified nerve growth factor. Biochemistry 1976: 15: 5543-5552.

16. Varon S, Skaper SD, Manthorpe M. Trophic activities for dorsal root and sympathetic ganglionic neurons in media conditioned by Schwann and other peripheral cells. Devel Brain Res 1981; I: 73-87.
17. Weston JA. The migration and differentiation of neural crest cells. Advances Morph 1970; 8: 41-114.

18. Mobley WC, Server AC, Ishii DN, et al. Nerve Growth Factor. New Eng J Med 1977; 297: 1096-1104, 1149-1158, 1211-1218.

19. Russell DS, Rubinstein LJ. Pathology of Tumours of the Nervous System. Fourth Edition. London: Edward Arnold, 1977. 